\title{
Han Dongfang (in collaboration with Michaël Sztanke), Mon combat pour les ouvriers chinois (My struggle for Chinese workers),
}

Paris, Michel Lafon, 2014, 290 pp.

\section{Chloé Froissart}

Translator. N. Jayaram

\section{CpenEdition}

\section{Journals}

Electronic version

URL: http://journals.openedition.org/chinaperspectives/6738

DOI: 10.4000/chinaperspectives.6738

ISSN: 1996-4617

\section{Publisher}

Centre d'étude français sur la Chine contemporaine

\section{Printed version}

Date of publication: 1 June 2015

Number of pages: $64-65$

ISSN: 2070-3449

\section{Electronic reference}

Chloé Froissart, « Han Dongfang (in collaboration with Michaël Sztanke), Mon combat pour les ouvriers chinois (My struggle for Chinese workers), », China Perspectives [Online], 2015/2 | 2015, Online since 01 January 2017, connection on 24 September 2020. URL : http://journals.openedition.org/ chinaperspectives/6738; DOI : https://doi.org/10.4000/chinaperspectives.6738 
this collection of essays nevertheless constitutes a reference text for the study of international monetary relations. Experts in this field pay special attention to China, understandably: in December 2014, the RMB ranked fifth for payments according to SWIFT, the global operator of international financial messages, thus confirming an extremely rapid growth rate, to the extent that the RMB should catch up with the yen in 2015 .

I Translated by N. Jayaram.

I Adrien Faudot is a PhD candidate in economics at the Centre for Research in Economics of Grenoble (CREG), University of GrenobleAlpes (adrien.faudot@upmf-grenoble.fr).

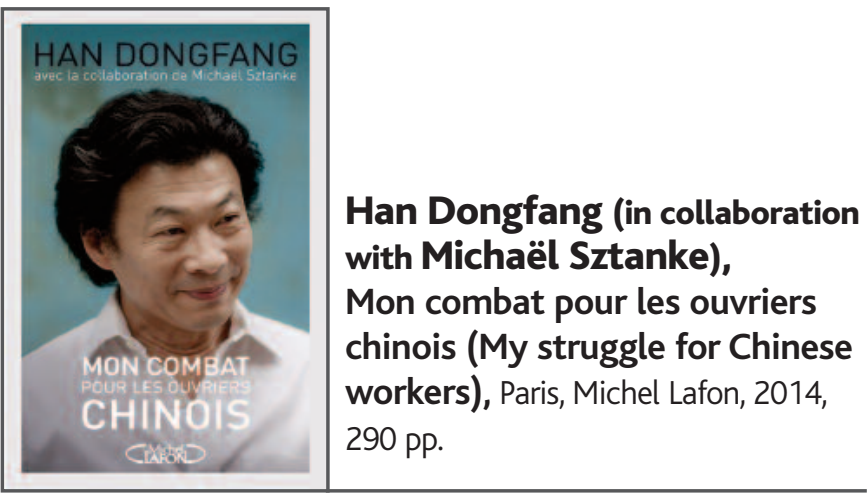

\section{CHLOÉ FROISSART}

$\mathrm{P}$ ublished in 2014 to mark the 20th anniversary of China Labour Bulletin (CLB), the book is based on interviews that French journalist Michaël Sztanke carried out with Han Dongfang, the prominent Chinese labour activist and founder of the Hong Kong-based CLB. Presented as a first person account organised chronologically as well as thematically, the book is divided into two parts: the personal journey of Han Dongfang (first five chapters), and CLB's activism (the following six).

The first part retraces the formation of a political consciousness right from adolescence, the time when Han joined the army before being employed as a railway worker, his participation in the 1989 Democracy Movement in Beijing and the creation of the first workers' autonomous federation, whose spokesman he became; imprisonment for 22 months, illness, his stay in the United States and the impossibility of returning to China. It lays stress on key figures and events that have informed this consciousness: his peasant mother, who sacrificed her marriage in order to ensure that her children received an urban education in Beijing, and who taught him to care for others; the January 1987 student demonstrations in support of Hu Yaobang and his policies of reform and opening, which were quelled by a police baton charge; and of course, the 1989 events that signalled Han's entry into politics.

Han could have had an altogether different destiny: as a migrant worker dependant on others, had he remained in the countryside with his father; or pursuing the path of the PRC's elites, given that as a great admirer of Lei Feng he was promoted to deputy chief of his regiment and applied to join the Communist Party: "I behaved like a real soldier serving the people," he stresses (p. 21). But his rebellious spirit willed otherwise. His distrust of hierarchy, his awareness of abuses of power within the army, and his wish to "live in truth," (1) so to speak, finally convinced him that the Party needed reform: he resolved to "become an actor for this change" (p. 23). The students who risked their lives to organise his evacuation from Tiananmen Square when the crackdown began sealed his destiny by giving him the mission to become China's Lech Walesa. This independent spirit manifested itself again and again, as when facing violence and humiliation in prison and afflicted with serious tuberculosis, he stubbornly refused to admit to any "crime," or when in the United States for ablation of a lung, he converted to Christianity while resolving not to belong to any church: according to him, faith had to remain in the private and intimate domain. And while in the United States, he grew determined not to join the dissident movement in exile but to return to his country and work for change from within. Turned back twice at the Chinese border he was trying to cross from Hong Kong, Han was stripped of his nationality and found himself stateless until the Hong Kong authorities issued him a passport in 1997.

Part Two of the book opens with his decision - or rather painful acceptance - to stay in Hong Kong and use the place as a base to pursue the struggle on behalf of Chinese workers with the founding of CLB. Han gradually managed to symbolically cross the border with two radio transmissions: China Labour Bulletin, which he has presented thrice weekly via Radio Free Asia since 1997, and Radio Express News, during which he interacts with Chinese workers, gathering and verifying information in order to present the facts on social events in China. Han has also breached the border with the help of colleagues at CLB and partners - lawyers and NGOs - in China who are his "eyes and ears" and help realise his objectives to "put in place a network of supportive workers" (p. 16) and facilitate the emergence of worker leaders.

The second part then turns to militant action, reflecting on this action and the search for strategies, not only to help workers defend their rights but also to promote lasting change. It provides a concrete and detailed description of CLB's action through successive battles: redress for xiagang (laid off) workers, justice for the families of workers who died in mine explosions and silicosis victims, and finally, the emergence of collective bargaining. Some of these battles helped advance matters incrementally, especially in terms of public policy: starting in 2002, the Ministry of Labour and Social Security (renamed the Ministry of Human Resources and Social Security in 2008) created its own website for disseminating information on mining accidents and has required local authorities to report them within 24 hours. Meanwhile, Gansu and Sichuan provinces have adopted a system to compensate silicosis victims, now that there is no question regarding the link between the disease and mining activities. CLB's advocacy has also influenced public opinion and has helped to open social space: today the media regularly report injustices against workers, and some local governments let "workers defend their interests without subjecting them to repression and harassment" (p. 168).

The organisation's elaboration of its methods and its positioning are set out through an analysis of exemplary cases, their impact, and what CLB has gleaned from them. This part is presented above all as an effort at defining and defending the organisation's action methods (CLB is not a union, but neither is it an "NCO for aid and advice," $p$. 109), addressed as much to the Chinese government as to dissidents in exile. To both sides, Han repeats that he is not a dissident but a labour rights activist, and that his work does

1. This expression is taken from Vaclav Havel, who explained it in his 1984 essay "Politics and Conscience," available at www.vaclavhavel.cz/showtrans.php?cat=clanky\&val=73_aj_clanky.html \&typ=HTML (accessed on 21 April 2015). 
not consist of fomenting revolution or fighting for democracy, but rather of protecting workers' interests within the existing system. For Han, democracy essentially consists of resolving concrete problems, especially through collective bargaining. Two recurring themes run through the book: on the one hand, distrust of ideology, especially grand theories on democracy, abstract objectives in whose name individual interests could be sacrificed; and on the other, the idea that effective action must necessarily be apolitical, that is to say, an action that helps to identify the meeting point for the interests of all party - workers, employers, and the authorities. To those who hoped he would become China's Walesa, Han's response is that the country has to find its own path and he abides by pragmatism: ex nihilo formation of independent unions is not a prerequisite for the emergence of collective bargaining; in practice, independent unions will emerge through such collective bargaining and from reforms within official unions.

$\mathrm{CLB}$ is thus representative of the new civil society born at the turn of the century, rising from the ashes of the 1989 Democracy Movement. Whereas that movement was characterised by demands for abstract rights, the current effort is toward the emergence of practical rights through their concrete exercise. It is also about taking into account - instead of ignoring the constraints of the authoritarian system to pursue a "constructive dialogue" with the party-state - which should also keep its part of the bargain - for defending the rights of individuals within the system itself. But will a civil society that seeks to abandon all political messages manage to have a political impact some day? Rejecting opposition and systematically pursuing compromises and win-win solutions that serve to smooth out social and political contradictions could merely lead to a dose of "harmonious democracy" that helps the regime preserve itself even longer...

Despite a relatively large number of typographical errors, anglicisms, and some repetition, Mon combat pour les ouvriers chinois is a reference text on more than one score: it provides a valuable account of militant activity in China and Hong Kong and of the evolution in the conditions of Chinese workers, especially stressing that they have become full-scale actors in the defence of their rights. It also raises fundamental questions concerning the role of workers and of civil society in the evolution of the Chinese regime.

I Translated by N. Jayaram.

IChloé Froissart is director of the Sino-French Academic Centre

(CFC), Tsinghua University, Beijing, and a researcher at CEFC, Hong Kong (chloefroissart@cefc.com.hk).

\footnotetext{
**This book review's digital version was updated on 30/10/2015 to edit slight translation inaccuracies**
}

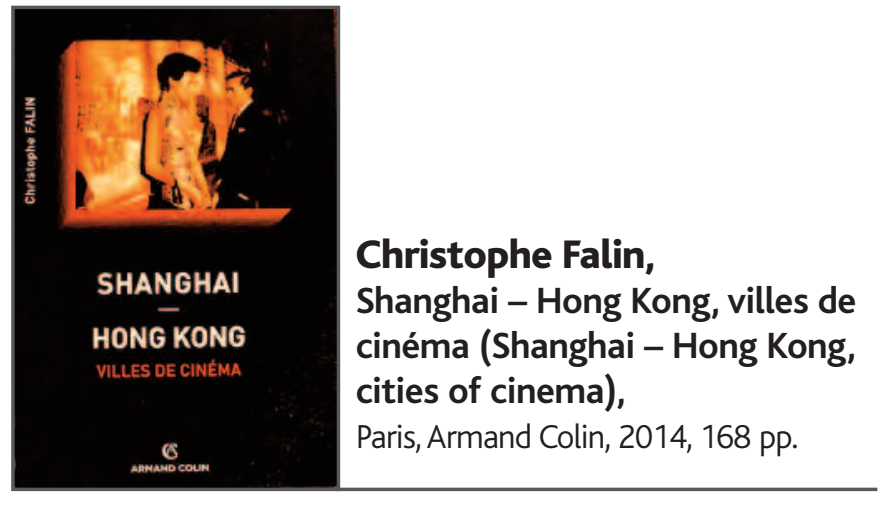

\section{LUISA PRUDENTINO}

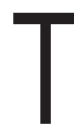
his work is dedicated to Shanghai and Hong Kong, two cities that occupy a mythical position in the eyes of the West and in Chinese cinema as, respectively, the birthplace of the industry in China and the place where it developed. Through their dual material and symbolic significance, the two cities continue to contribute to the history of cinema to this day.

The author has divided the book into three sections. The first is given over to the history of Chinese cinema in the two cities, and in particular to the exchanges that took place between the two over the course of the twentieth century. In this section, Christophe Falin reveals the major events that resulted in these exchanges, from the birth of sound film to the handover of Hong Kong to China in 1997, also observing the Sino-Japanese War (1937-1945) and the Communist victory of 1949. This section also includes an interesting paragraph concerning the mixing of Chinese cinema in the 1950s, resulting from the creation of two flagship companies in Hong Kong, MP\&GI and Shaw Brothers, which made this city into one of the most important centres for film production in Asia. Of course, the importance of these two studios in Hong Kong cinema at the time (and even afterwards) is well known, but there is precious little awareness of the strategic role they played in the distribution of film throughout Southeast Asia as a whole. From Malaysia to Singapore, every step in the creation of a film was controlled by these two companies, from the producers and directors through to the scriptwriters, actors, and technicians.

The second section covers the many ways in which Shanghai and Hong Kong have been portrayed in Chinese and Western films since the 1930s. The aim of the author is to show how the urban planning of the two cities has helped create an image of the two that is as real as it is fantastic. The reader is taken on a tour of Shanghai's 1930s lilong, which were, according to the author's definition, "aligned rows of two-level houses, built from brick," thus revealing both the luxurious properties of the foreign concessions and also the extreme poverty of the city's slums. The chapter covering Hong Kong and its overpopulated and hyperactive neighbourhood of Tsim Sha Tsui, which has provided the backdrop for many Chinese and foreign thrillers, contains even richer descriptions.

Finally, the third section is given over, in particular, to three major directors with close links to their cities: Lou Ye of Shanghai, and Wong Kar-wai and Johnnie To of Hong Kong. The author portrays Lou Ye as the natural heir to the generation of Chinese urban film-makers who emerged at the start of the 1990s, following the crackdown on the student movement at Tiananmen Square. Lou Ye's portrayal of Shanghai, the city of his birth, is lucid, even disillusioned. Wong Kar-wai, meanwhile, has a more intense bond with 